\title{
Physical Fitness Test through Portfolio Assessment
}

\author{
Komarudin \\ Sport Coaching Education Study Program \\ Universitas Pendidikan Indonesia \\ Bandung, Indonesia \\ Email, komarudin_pko@upi.edu
}

\begin{abstract}
Students' achievement in learning physical education has been measured using traditional assessment. The assessment, however, is considered partial so that it can only assess few parts of the whole learning activities. It usually results in the outcome without considering any learning processes, both inside and outside schools. To that relation, portfolio assessment appears to be an alternative to evaluate students' achievement as well as performance authentically. Using this type of assessment, teachers will be able to capture students' learning processes entirely. This study aims to find out the influence of portfolio assessment to enhance students' physical fitness. This study employed a quasi-experimental method using pretest-posttest control group design. The population involved in this study eighth graders and the sample is two classes of them selected using cluster random sampling, and the instrument used in fitness-gram test (one-mile run). The data are then analyzed using $t$ test. From the data obtained, it has been proven that portfolio assessment is more effective than the traditional one to enhance students' physical fitness. Finally, this study suggests that schools use portfolio to measure students' physical fitness since this type of assessment is more authentic in comparison with the traditional one.
\end{abstract}

Keywords- Physical fitness, portfolio assessment, and traditional assessment.

\section{INTRODUCTION}

Traditional assessment in a form of test has several shortcomings, traditional assessment approach mostly promotes students to memorize rules or algorithms rather than conceptual understanding, and focus on small, discrete components of the domain (1) traditional assessments measure common and narrowly defined knowledge that is incompatible with the aim of any robust education for lifelong learning (2). In the other than that this tests help measure a discrete skill or the recall of discrete information, but are limited when gathering evidence about the application of these abilities in a "real-life" context (3).

These traditionally objective tests seem to be irrelevant since resembles capturing students' behaviors regardless the context of learning and this is considered in comprehensive. Thus, this type of assessment has shallow meanings in educational perspective and tends to be unfair since the final result is more of teachers' decisions. That is why assessment based on test results so many criticisms. Thus, this type of assessment is in need of review to improve the quality of learning, especially in physical education. In physical education, assessment needs to comprehensively measure things in relation to knowledge, attitude, and skills, either inside or outside schools. In other words, assessment should integrate with the teaching and learning processes both inside and outside schools so that active lifestyle, which is one of the final objectives of physical education, can be achieved.

To do so, teachers also face several challenges. One of them is a very popular issue among youths surrounded with values shift from "survival society" to "excitement society". This shift; however, affects a change in movement culture or life-style. In an attempt of answering this challenge, there has to be an upgrade in developing teaching experiences in a form of meaningful movements to achieve learning goals. A big challenge behind this phenomenon is the birth of "motionless" generation. The effect of this life style factors are responsible degenerative and chronic diseases that afflict human being in recent times. Such degenerative diseases are hypertension, diabetics, cancer, stroke and liver diseases including the spread of HIV/AIDS (4).

To cope with the aforementioned issues, portfolio assessment is an alternative choice that is able to review actual tendencies and critical issues among society, including students. In portfolio assessment, students' learning processes are reviewed in a meaningful way. By doing so, students' experiences in the teaching and learning process are taken into consideration. In addition, this assessment can also answer a radical change in physical education theories and practices that demand to respond to a threat of motionless children who turn into obese ones.

It is believed that portfolio assessment can provide information that measure students' physical fitness comprehensively. Portfolios appear to be a possible means to promote comprehensive, authentic and integrated learning and may also promote active engagement in learning activities (5). Portfolio as a collection of student work; an opportunity for student selection of items for inclusion in the portfolio; active student engagement in the assessment process by demonstrating through evidence what he or she knows and can do; student self-assessment on progress and accomplishments; and reflection on the process and the value of the learning itself (6).

Those research findings prove that portfolio provides comprehensive information and improves students' motivation and responsibility to keep learning. In the context of physical education in Indonesia, there is very limited information on portfolio assessment related to physical education, especially related to the improvement of students' physical fitness. Based on this evidence, the research question is "does portfolio 
assessment give significant influence to the improvement of students' physical fitness?"

Assessment usually focuses more on the results and neglects processes. Even though, results in teachers focusing teaching on the test content, training students in how to pass tests, and adopting teaching styles which do not match the preferred learning style of many students. In these circumstances teachers make little use of assessment formatively, to help the learning process (7). Assessment focuses on the product, as well as the quality of performance, and students are more actively involved in the learning process (2). The essence of the previous theory is that teaching, learning, and assessment are integrated in the process of teaching and learning. Physical education teachers, in reality, still use traditional type of assessment, which seems to focus merely on the results without considering the learning processes. Traditional assessment is not inauthentic, it is simply less direct and, probably, less meaningful to students. Is not faithful to the domains of performances and contexts that are most important for higher order thinking and learning (8).

In another opinion, it is explain that it is provide less useful information about students' understanding and learning are not enough to assess higher order cognitive skills such as problem solving, critical thinking and reasoning, not measure a students' ability to organize relevant information, and assess what is easy to test-memorization of rote skills and procedures (1). Commonly, in physical education, assessment is meaningless; it is not well integrated into the process of teaching and learning. For instance, students' understanding and adequate feedback giving are rarely found. What usually happens in the field is that teachers give regular assessment for the sake of formality without thinking about the upcoming feedback to enhance the next processes.

\section{METHOD}

This study administers experimental method using the randomized pretest-posttest control group design. The population of this study consists of six classes of eighth graders at SMP YAS Bandung. Selected through a cluster random sampling, the sample of the study is two classes out of the population above. Both classes are the categorized into class A (experimental group which receives the treatment of physical education with assessed by portfolio assessment) and class D (control group which receives physical education with assessed by traditional assessment).

To collect the data needed, this study uses fitness-gram test (one mile run) to measure students' physical fitness, anecdotal record, physical activity and leisure questionnaire to measure students' activities inside and outside schools, and also fitness workout schedule (10). Those instruments are not only administered in the pretest and posttest, but also in every unit of the teaching and learning process to find out the development of students' learning outcome. Basically, in the traditional type of instruments, the foundational principles are similar yet the differences lie on several ones such as outside school activity and daily behavior instruments. To test the hypothesis, the current study utilizes t test (paired t test and independent $t$ test) using SPSS 21 for Windows.

\section{RESULT}

The data, which are students' physical fitness, collected through the process of calculation in this study are analyzed using statistical approach. The results of pretest, posttest, and the difference of each score are in Table I. below.

TABLE I. THE RESULTS OF PRETEST, POSTTEST, AND DIFFERENCE OF SCORES

\begin{tabular}{|l|l|l|l|l|c|}
\hline \multicolumn{2}{|c|}{ Portfolio Assessment } & \multicolumn{3}{c|}{ Traditional Assessment } \\
\cline { 1 - 4 } Item & Mean & $\begin{array}{l}\text { Differenc } \\
e\end{array}$ & Item & Mean & $\begin{array}{l}\text { Differenc } \\
e\end{array}$ \\
\hline $\begin{array}{l}\text { Pre } \\
\text { Test }\end{array}$ & 12.4396 & \multirow{2}{*}{1,5429} & $\begin{array}{l}\text { Pre } \\
\text { Test }\end{array}$ & $\begin{array}{c}12.140 \\
2\end{array}$ & \multirow{2}{*}{0,1476} \\
\cline { 1 - 1 } $\begin{array}{l}\text { Post } \\
\text { Test }\end{array}$ & \multirow{2}{*}{10.8967} & & $\begin{array}{l}\text { Post } \\
\text { Test }\end{array}$ & $\begin{array}{c}11,992 \\
6\end{array}$ & \\
\hline
\end{tabular}

Based on the statistical calculation above, it is proven that portfolio has higher score difference than traditional assessment.

\section{HYPOTHESIS TESTING}

In testing the hypothesis, this study employs paired sample $t$ test and independent $t$ test. This aims to capture the influence from pretest and posttest as well as to investigate the influence between portfolio and traditional assessments to the improvement of students' physical fitness. The results are as follows (in Table II). 
TABle II. THE RESUlts of ANALYSIS OF PAIRED SAMPLE T TESTSCORES OF PRETEST AND POSTTEST BETWEEN PORTFOLIO AND TRADITIONAL ASSESSMENTS

\begin{tabular}{|c|c|c|c|c|c|c|c|c|}
\hline & \multicolumn{5}{|c|}{ Paired Differences } & \multirow{3}{*}{$\mathrm{t}$} & \multirow{3}{*}{ df } & \multirow{3}{*}{$\begin{array}{l}\text { Sig. } \\
(2- \\
\text { taile } \\
\text { d) }\end{array}$} \\
\hline & & & & \multicolumn{2}{|c|}{$\begin{array}{c}95 \% \\
\text { Confidence } \\
\text { Interval of } \\
\text { the } \\
\text { Difference }\end{array}$} & & & \\
\hline & Mean & $\begin{array}{c}\text { Std. } \\
\text { Deviati } \\
\text { on }\end{array}$ & $\begin{array}{l}\text { Std. } \\
\text { Error } \\
\text { Mean }\end{array}$ & $\begin{array}{c}\text { Lowe } \\
r\end{array}$ & $\begin{array}{c}\text { Uppe } \\
\text { r }\end{array}$ & & & \\
\hline $\begin{array}{c}\text { Pretest- } \\
\text { Posttest } \\
\text { KJ } \\
\text { Portfolio } \\
\text { Assessm } \\
\text { ent }\end{array}$ & $\begin{array}{c}1.542 \\
9\end{array}$ & .82298 & $\begin{array}{c}.1213 \\
4\end{array}$ & $\begin{array}{c}1.298 \\
43\end{array}$ & $\begin{array}{c}1.787 \\
22\end{array}$ & $\begin{array}{c}12.71 \\
5\end{array}$ & 45 & .000 \\
\hline $\begin{array}{c}\text { Pretest- } \\
\text { Posttest } \\
\text { KJ } \\
\text { Tradisio } \\
\text { nalAsses } \\
\text { sment }\end{array}$ & .1476 & $\begin{array}{c}3.4326 \\
7\end{array}$ & $\begin{array}{c}.5061 \\
2\end{array}$ & $\begin{array}{c}- \\
.8717 \\
7\end{array}$ & $\begin{array}{c}1.166 \\
99\end{array}$ & .292 & 45 & .772 \\
\hline
\end{tabular}

The calculation above shows that the (sig) value is lower than 0.05 , which means that Ho is rejected. This implies that there is significant influence of portfolio assessment towards the improvement of students' physical fitness. Furthermore, the (sig) value of traditional assessment is bigger than 0.05 meaning that Ho is accepted. This implies that there is no significant influence of traditional assessment towards students' physical fitness. To conclude, it is proven from the results of pretest and posttest that portfolio assessment is more influential than traditional one towards the improvement of students' physical fitness. The results are in Table III. Below.
TABLE III. THE RESULTS OF INDEPENDENT T TEST BETWEEN PORTFOLIO ASSESSMENT AND TRADITIONAL ASSESSMENT

\begin{tabular}{|c|c|c|c|c|c|c|c|c|c|c|}
\hline \multicolumn{11}{|c|}{ Independent Samples Test } \\
\hline & & \multicolumn{2}{|c|}{$\begin{array}{l}\text { Levene's } \\
\text { Test for } \\
\text { Equality of } \\
\text { Variances }\end{array}$} & \multicolumn{7}{|c|}{ t-test for Equality of Means } \\
\hline & & \multirow[t]{2}{*}{$\mathrm{F}$} & \multirow[t]{2}{*}{ Sig. } & \multirow[t]{2}{*}{$\mathrm{t}$} & \multirow[t]{2}{*}{ Df } & \multirow[t]{2}{*}{$\begin{array}{l}\text { Sig. } \\
(2- \\
\text { taile } \\
\text { d) }\end{array}$} & \multirow[t]{2}{*}{$\begin{array}{c}\text { Mean } \\
\text { Differ } \\
\text { ence }\end{array}$} & \multirow{2}{*}{$\begin{array}{c}\text { Std. } \\
\text { Erro } \\
r \\
\text { Diff } \\
\text { eren } \\
\text { ce }\end{array}$} & \multicolumn{2}{|c|}{$\begin{array}{c}95 \% \\
\text { Confidence } \\
\text { Interval of } \\
\text { the } \\
\text { Difference }\end{array}$} \\
\hline & & & & & & & & & $\begin{array}{c}\text { Low } \\
\text { er }\end{array}$ & Upper \\
\hline \multirow[b]{2}{*}{$\begin{array}{c}K \\
J\end{array}$} & $\begin{array}{l}\text { Equal } \\
\text { varian } \\
\text { ces } \\
\text { assum } \\
\text { ed }\end{array}$ & \multirow{2}{*}{$\begin{array}{c}15.13 \\
7\end{array}$} & \multirow[b]{2}{*}{.000} & $\begin{array}{c}3.07 \\
2\end{array}$ & 90 & .003 & $\begin{array}{c}1.395 \\
22\end{array}$ & $\begin{array}{c}.454 \\
18\end{array}$ & $\begin{array}{c}.492 \\
92\end{array}$ & $\begin{array}{c}2.297 \\
52\end{array}$ \\
\hline & $\begin{array}{c}\text { Equal } \\
\text { varian } \\
\text { ces } \\
\text { not } \\
\text { assum } \\
\text { ed }\end{array}$ & & & $\begin{array}{c}3.07 \\
2\end{array}$ & $\begin{array}{c}51.8 \\
77\end{array}$ & .003 & $\begin{array}{c}1.395 \\
22\end{array}$ & $\begin{array}{c}.454 \\
18\end{array}$ & $\begin{array}{c}.483 \\
80\end{array}$ & $\begin{array}{c}2.306 \\
64\end{array}$ \\
\hline
\end{tabular}

The calculation above depicts that the sig (2-tailed) value is lower than 0.05 meaning that Ho is rejected. It is then safe to conclude that there is significant influence between portfolio assessment and traditional assessment towards the improvement of students' physical fitness. In the meantime, the data show that the mean difference of portfolio assessment is higher than that of traditional one indicating that portfolio assessment performs better than traditional assessment.

\section{DISCUSION}

It has been proven that portfolio assessment performs better than traditional assessment towards the improvement of students' physical fitness. One of the reasons is that in portfolio assessment students will participate in learning experience designed to improve fitness, promote health, and prevent future disease. The goal of the fitness for life course is to make sure you have the chance to engage in physical activity during physical education class and to encourage you to participate in physical activity outside of school and throughout your life (10). Physical fitness is actually students' personal issues, thus they need their own ways to develop, keep, and monitor their physical fitness program. In portfolio assessment, the growth of students' personal behavior is monitored through a compilation of student activities recorded using fitness workout schedule and physical activity and leisure questionnaire. This format describes students' physical activities in their leisure time so that teachers can filter information in relation to activities supporting the improvement of students' physical fitness.

Additionally, students also understand that the development of health-related physical education should 
belinked with the use of a more authentic assessment that addresses objectives such as understanding the goals of each type of physical exercise, how to perform them correctly, selfregulation, physical activity levels, behaviour change, engagement and students responsibilities in the programmes. Students were given homework assignments one or two times per week and each assignment, it is found that students significantly improved their Health Related Fitness (HRF) knowledge (9). Therefore, portfolio assessment is able to show the description of students' activities supporting their physical fitness improvement. Moreover, this type of assessment is also able to enhance their active lifestyle since students get used to doing various physical activities as the results of their learning outcome in schools. In the implementation, students are able to develop a personalized program, students seek to improve achievement while working together on a group project to evaluate the fitness needs of family members, design custom programs, provide training, and monitor progress students "understand how to monitor and maintain a health-enhancing level of physical fitness (3).

In traditional assessment, there are only such tests as written test to measure students' theoretical understanding of the materials, article summary to test their physical fitness program, and an essay to see a case study. This type of assessment is not entirely incorrect; however, it is unable to describe students' physical activities and other supporting activities affecting their physical fitness improvement. On the other hand, portfolio assessment is considered authentic since it answers the need for more naturalistic, performance-based approaches. In physical education, a skill could be assessed by observing a student performing in naturalistic game settings and checking it against a rating scale, instead of rating the performance of this skill in isolation (e.g., test station) (3). Besides, all students, with no exception, need to do the movement being practiced. There cannot be any students get left behind since students can experience the real movements by doing them. In fact, physical fitness needs to be maintained to achieve dynamic health and dynamic health can only be reached by paying attention to moderate intensity.

\section{CONCLUSION AND RECOMMENDATION}

Based on the data analyzed in this study supported by the theoretical framework elaborated above, it can be concluded that portfolio assessment performs better that traditional assessment towards the improvement of students' physical fitness. Therefore, it is recommended that practitioners pay attention to students' active participation by involving projects that describe students' activities outside schools since it is one of the active lifestyle indicators that contribute positively in improving students' physical fitness.

\section{ACKNOWLEDGEMENTS}

This article would not have been possible without the contributions of many other people, and I would like to acknowledge the ways in which others have helped me throughout this process. I would like to thank to headmaster for allowing me the opportunity to conduct this study. In particular, I would like to thank to physical education teachers, which help me in the intervention process and completing this study. I am especially grateful to the international conference committee (ICEMAL) who reviewed this article, for guidance in preparing and submitting in proceeding indexed. Finally, I would like to thank to my friends and family, especially to my wife and children, for all of their support (both direct and indirect) to completing this article.

\section{REFFERENCES}

1. Faculty E. The Use of Portfolio to Assess Student's Performance. 2007;4(2):75-90.

2. Mintah JK. Authentic Assessment in Physical Education : Prevalence of Use and Perceived Impact on Students 'Self-Concept , Motivation , and Skill Achievement. 2003;7(3):161-74.

3. Melograno VJ, Melograno VJ. Designing a Portfolio System for K-12 Physical Education: A Step-by-Step Process Designing a Portfolio System for K - 12 Physical Education: A Step-by-Step Process. 2015;7841(December)

4. Journal E, Studies E, Vol M. Ethiopian Journal of Environmental Studies and Management Vol. 6 No.3 2013. 2013;6(3):273-9.

5. Vaughan B, Florentine P, Carter A. Introducing a portfolio assessment in a pre-professional osteopathy program. Int J Osteopath Med [Internet]. 2013;6-11. Available from: http://dx.doi.org/10.1016/j.ijosm.2013.06.003

6. Klenowski V. Portfolio Assessment. 2010;236-42.

7. Arlen WYH, Rick RUTHDEC. Testing and Motivation for Learning. 2003;10(2).

8. Bruce B, Vicki L, Allen JP. Defining Authentic Classroom Assessment. 2012;17(2).

9. Keating XD, Harrison L, Chen L, Xiang P, Lambdin D, Dauenhauer B et al. An Analysis of Research on Student Health-Related Fitness Knowledge in K - 16 Physical Education Programs. 2009;333-49.

10. Melograno, V.J. (2006). Professional and Student Portfolios for Physical Education. Second Edition. Human Kinetics. 